\title{
ICT, INTERMEDIARIES, AND THE TRANSFORMATION OF GendeREd POWER STRUCTURES ${ }^{1}$
}

\author{
Elisa Oreglia \\ Wee Kim Wee School of Communication and Information, Nanyang Technological University, \\ 04-39 Nanyang Link, SINGAPORE 637718 \{eoreglia@ntu.edu.sg\} \\ Janaki Srinivasan \\ International Institute of Information Technology, 26/C, Electronics City, Hosur Road, \\ Bangalore, Karnataka 560100 INDIA \{janaki.srinivasan@iiitb.ac.in\}
}

\begin{abstract}
Information and communication technologies (ICTs) are believed to hold much potential to empower women, both socially and economically, in low-income and rural communities. In this paper, we focus on rural women who mediate ICT use as telecenter operators in India and as helpers and enablers for family members in rural China. We explore under what circumstances they may be able to renegotiate existing gendered power structures. We argue that acts of reconciling or confronting the different spaces they inhabit can allow intermediaries to remake their own identities and positions in their community. This process, rather than the potential associated with ICTs, is where spaces for empowerment often lie.
\end{abstract}

Keywords: Gender, intermediaries, Global South, China, India, ICT, mobile phones, telecenters

\section{Introduction}

Since the late 1990s, personal information and communication technologies (ICTs) such as mobile phones have become increasingly available among low-income communities around the world, thanks to the combination of technological advancements and falling costs. This was followed by widespread optimism over their potential to bring about significant societal and economic transformations. But, as the call for papers of this Special Issue reminds us, large-scale adoption of ICTs is a constant negotiation between enabling and constraining solutions to society's challenges. An example of such challenges is the issue of women's empowerment in low-income communities, which was hailed early on as one of the areas where ICTs could make a significant and positive

\footnotetext{
${ }^{1}$ Ann Majchrzak, M. Lynne Markus, and Jonathan Wareham were the accepting senior editors for this paper.
}

impact. $^{2}$ In this paper, we draw on our ethnographic fieldwork on female ICT intermediaries in rural China and India to examine the specific processes through which women negotiate gender dynamics and power structures within their families and their villages around ICT use, and to show that women renegotiate their gender roles more through the process of mediating ICT access for others than in their personal use. We find that rather than the preconceived potential associated with ICT use, it is in this process of intermediation that

\footnotetext{
${ }^{2}$ The female operators of the Grameen Foundation Village Phone are a powerful symbol of this potential in both academic (Cohen 2001; Stanley 2005) and other venues (The Economist 2009; Gill et al. 2010; Malhotra et al. 2012). This and similar accounts emphasize the fact that empowerment through ICT happens because women can have new careers (e.g., as phone operators), and improve their economic conditions, by having more choices and developing new skills. Recent academic research has portrayed a more nuanced view of such changes, showing, for example, how women's access to ICT can be easily lost to male family members (Burrell 2010; Wallis 2012a).
} 
spaces for empowerment are forged. Connectedly, we find that temporary gains in the status of individual women facilitated by the process of ICT intermediation are easily reversed if ICTs are not part of broader social changes, especially in the structure of patriarchal organization. The rest of the paper is organized as follow: We begin with a literature review that introduces our key concepts of intermediation and empowerment. We then describe our methods, and follow with two sections that discuss findings in the contexts of change versus maintenance of status quo. This is followed by the conclusion.

\section{Empowerment Through} Intermediation?

Information systems (IS) research has highlighted that ICT users are social actors rather than atomistic individuals; that is, they interact with multiple people, multiple ICTs, and a variety of social contexts (Lamb and Kling 2003). Further, the research has found that intermediaries play an important role in facilitating processes of knowledge reuse within information systems (Markus 2001). Both of these aspects are important to us as we explore the role of ICT intermediaries in processes of social change, but our research investigates ICT use in the Global South, in very different geographical, economic, and social settings than the setting in which traditional IS research takes place. Therefore, to investigate the role that intermediaries play in the adoption of ICT in such non-Western and noncorporate settings, we additionally draw on the field of information and communication technologies and development (ICTD). This area of research has drawn attention to the fact that ICT design has traditionally focused on corporate settings in the West, on individual device ownership, and on use by literate users. These conditions are at odds with ICT use in places where users are not necessarily literate (Donner and Marsden 2011; Medhi et al. 2010; Parikh 2006), they may not own the devices they use, and their use may also not be individual (Burrell 2010; Pal et al. 2006).

In all of these circumstances, intermediation, defined by Sambasivan et al. (2010, p. 2583) as what "occurs when the primary user is not capable of using a device entirely on their own," forms a key part in the daily use of ICTs for many people (see also Parikh 2006; Sukumaran et al. 2009). Existing research has looked mostly at public access ICTs and mediation outside of the family (Kumar and Best 2006; Kuriyan et al. 2006; Ramírez et al. 2013), and we extend this to circumstances where intermediation happens within the family, or where the consequences of one's job as an intermediary are experienced by family members. Our work seeks to understand the unintended consequences that being an intermediary in ICT use has for young rural-to-urban migrant women in China, who spend time in urban areas, learn how to use ICTs, and pass this knowledge on to family members; and for women who work as telecenter operators to support villagers' use of computers in rural India. We show that the role of intermediaries has intended consequences, such as teaching other people how to use ICTs, but also unintended ones, such as the negotiation and restructuring of power structures within the family. We argue that these female intermediaries leverage the process of ICT intermediation to carve out spaces of empowerment, which, following Kabeer (2001, p. 19), we understand as "the expansion in people's ability to make strategic life choices in a context where this ability was previously denied to them." The emphasis here is on the process of change, rather than its outcome, and on the agency of women in this process. ${ }^{3}$ The "ability to make strategic life choices" (p. 19) highlighted by Kabeer is only real in a context where choices exist and are recognized as such, at least discursively, and where making them does not come with "punishingly high costs" (p. 26). In our cases, we study the expansion of choices that are materially available to women, as well as in their recognition of alternatives hitherto unfamiliar to them in the course of mediating ICT use.

Our focus on women ICT users is not accidental. Adam et al. (2004) pointed out that gender had been largely left out of mainstream IS research, with little efforts at theorizing and integrating perspectives from the gender and technology scholarship, and a narrow focus on gender as a binary variable that determines differences in behavior, while ignoring age, ethnicity, and class. Ten years on, many of the issues raised in that paper remain relevant, especially regarding gender as a dichotomous category (Trauth 2013). While there are signs of increasing diversity, with theoretically sophisticated research on gender and IS (Corneliussen 2005; Pozzebon et al. 2014; Richardson 2009; Tapia 2006; Trauth 2013), on the integration of critical theory in IS research (Adam et al. 2006; Howcroft and Trauth 2008; Richardson and Howcroft 2006; Trauth and Howcroft 2006), and on race in IS (D'Mello and Eriksen 2010; Kvasny 2006; Ravishankar et al. 2012), these interventions constitute the exception rather than the rule.

We find the case of female intermediaries a useful one to examine the broader theme of women's empowerment and ICTs for two reasons. The first is that the process of ICT mediation straddles the domains of work and family, long recognized as equally important and interconnected arenas of

\footnotetext{
${ }^{3}$ A change in ability to make choices might be related to the conditions under which choices are made (resources), the process by which choice is made (agency), and the outcome of choices (achievement). See also Malhotra et al. (2002) for a broader survey of the challenges with defining and measuring empowerment.
} 
social change when talking of changes in women's roles. The second reason is that being an intermediary, a role that was largely unanticipated by ICT designers and largely unacknowledged by its users, offered a choice that was previously not available to women. In studying this theme, we also attempt to address the tension between universal metrics and context-dependent definitions of empowerment long faced by those studying or measuring women's empowerment (Kabeer 2001; Malhotra et al. 2002). We do so by using cases from two countries and sites to examine the same question: how the process of mediating ICT use can simultaneously be a process of empowerment, with unpredictable results.

\section{Methods}

We base this paper on ethnographic fieldwork carried out by the first author among Chinese rural-to-urban migrant women, who mediate ICT access in their native, rural communities, and by the second author among women who operate public access telecenters in rural India. The fieldwork in China focused on ICT use among migrant workers in Beijing, and in their home villages in the Northern provinces of Hebei and Shandong (Oreglia 2013). The fieldwork in India focused on the operators of village telecenters in the southern Indian states of Tamilnadu and Puducherry. These centers were part of two broader telecenter projects. The Sustainable Access in Rural India project (SARI) was established in Tamilnadu in 2001 and operated by a microcredit NGO (Srinivasan 2012). The Information Village Research Project (IVRP) was set up and operated by an agricultural research NGO in Puducherry since 1998 (Srinivasan 2011).

Our fieldwork included open-ended and semi-structured interviews, observation, and participant observation in research participants' homes, workplaces, and villages between 2004 and 2011 (fieldwork details are presented in Appendix A; the names we use in this paper are pseudonyms). In the tradition of ethnographic research, we assessed whether we had sufficient material by gauging data saturation, that is, whether themes were being repeated by interviewees, rather than by the number of people with whom we spoke (Saumure and Given 2008). Longitudinal research offered us a way to observe social changes that unfolded over several years through repeated negotiations, changes that were difficult to quantify and measure, and seldom had a single outcome. As we will see in the next section, this method is particularly helpful in understanding women's empowerment as a process (Malhotra et al. 2012), the focus of our analysis.

The Chinese and Indian cases offer particularly interesting instances of ICT intermediaries. In Chinese villages, growing ownership of cheap smart-phones or Internet-ready feature phones (CNNIC 2013), and good coverage and cheap data plans, make the Internet increasingly accessible to locals. Rural-to-urban migrants also maintain close ties with their native villages, and bring ICT and know-how on ICT back home (Oreglia and Kaye 2012). These migrants are typically young people, both females and males, who leave the village after finishing middle or high school, and who return at least once a year at Spring Festival, or for longer periods. In their urban experience, they become very skilled at using ICTs to remain in touch with family and friends, for entertainment, and often for work. In the Indian case, NGO-sponsored public telecenter projects became a popular form of offering ICT access in villages in the 2000s. Some of these projects (including the ones on which we focus) explicitly emphasized women's ICT access. NGOs established village-level telecenters and employed operators to run them. In the cases we examined, the NGOs focused on women's empowerment and emphasized bringing in female operators. ${ }^{4}$ The primary work of these operators was to instruct visitors on ICT use, including conducting elementary software classes for children and young adults, helping visitors browse or look up specific websites, or looking those up on behalf of visitors. The choice of operators has long been seen as crucial to the health of such projects and this made ICT intermediaries important actors in a village community (Gopakumar 2008; IIITB 2005; Srinivasan 2012).

The empowerment framework we outlined earlier allows us to examine what mediating ICT use meant for female intermediaries, and we undertake this in the following section.

\section{A Push to Change Through ICT Mediation}

In this section, we examine how acquiring a mobile phone and teaching other people how to use it in the case of Chinese migrant women, or controlling access to a computer, as in the case of Indian women working in telecenters, affects the lives of these intermediaries. Using Kabeer's (2001) definition of empowerment, we analyze processes of change in these women's lives, paying attention to how they recognize and leverage the new opportunities that their roles as intermediaries make available to them. We find that, first, they gain prestige for technical proficiency within the family and the wider community, given that ICTs were seen as sophis-

\footnotetext{
${ }^{4}$ In addition to their gender identity, operators also brought a history of relations with the community in which they are working (operators were recruited either from the same village they lived in or from adjacent villages). To that extent, even before they started working at the center, intermediaries are also perceived and judged by the moral standards of the community.
} 
ticated technologies identified with male, urban, and educated users. The second gain is through expanded economic opportunities. In the Chinese case, the possession of a mobile phone or, even more, a computer is often a sign of a certain financial independence; in the Indian case, working at a telecenter is a way for women to earn money and contribute to the family finances, rather than depending on the (male) breadwinner. Both cases, however, are replete with social tensions around what is considered appropriate behavior for women, and gains in prestige and economic independence can be easily lost.

In the Chinese countryside, a strong patriarchal system persists, but the combined experiences of migration, urban life, and work have ignited serious tensions around traditional gender roles. Millions of young women leave their villages to improve their chances in life, or "see the world," as they often put it (Fu 2009; Yan 2003), but also to help with the family finances. Once in the city, they experience the independence that comes with having their own income, even if limited, and with living their own lives away from the eyes of the village. What emerged clearly from interviews and observation was that going back home, even temporarily, and to the position of subordination that young women traditionally have to maintain in front of men and older women could be very difficult, especially for women with significant influence over the financial situation of their family through their remittances. Open rebellion, such as a direct refusal to send money back home, appeared to be rare; what was more common was a pro forma respect of traditional roles, while subverting them in subtle ways that are concretized through, in particular, money and ICTs. Both represented a hardearned independence; ICTs also signified technical competence, as well as the ability to carve one's space and to communicate with whomever one chose, beyond the control of the family.

The story of Ling Hua may illustrate some of these issues. She grew up in the countryside of the central province of Shaanxi, the second of three children, and migrated to Beijing right after graduating from middle school. She sent money home to help support her parents (both farmers), and to keep her younger brother in school at first, and subsequently to help him get married and buy a house. When she first arrived in Beijing, in the early 2000s, she saved up everything she earned for 6 months. She sent half of the money to her parents, and she used the other half to buy herself a mobile phone - a common occurrence among young migrant women who want to establish their urban credentials, and have a tangible sign of having made it in the city (Wallis 2012b). Soon after, she started to save money to buy a cheaper mobile phone to give to her mother. Remaining in touch with her was very important for Ling Hua, but it was complicated: her parents' house did not have a landline, and so she had to phone her uncle, ask him to find her mother, then call back a few minutes later to see if she was around and free to talk. It was cumbersome and expensive, and Ling Hua decided to bypass the landline by buying a phone for her mother. Her father was not pleased, since he did not have one yet, but Ling Hua was adamant that the phone belonged to her mother, and that since it was her money that bought it, she could do what she pleased. She taught her mother how to use it to make and receive calls (text messages were beyond the literacy level of the mother), and sent her money to buy airtime. Her father was cut off from the conversation entirely, and her mother was one of the first mobile phone owners in the village. This upset the family relations: when Ling Hua called the landline she would occasionally talk with her father, but after she gave her mother a mobile phone, she only talked to her. As Ling Hua recounted it, at the end of her calls with her mother, she would ask if her father had anything to say. "Is there anything?" the mother would ask the father. "Nothing" would be the typical answer, and that represented the end of the conversation.

Ling Hua's case is not isolated, and her typical phone conversation with her father - "Is there anything?" "Nothing" - was repeated verbatim by several other migrants in Beijing, both females and males. ICTs have opened up new spaces of intimacy between mothers and migrant daughters (and often sons), where children mediate their mothers' use of ICTs and teach them (often over and over again) how to use a mobile, or find content that their mothers would enjoy such as music or e-books and then teach them how to access it. This contributes to a slow change in the expectations that exist around the role of women within the family, reinforcing a pattern of change that has been taking place in other areas for some time (Fan 2004; Gaetano and Jacka 2004). But a further challenge to their role comes from migrant daughters' exposure to different codes of behavior they experience in urban settings, especially around personal freedom. In purchasing phones for their mothers and not their fathers, in instructing them in their use, in finding appropriate content, the migrant women enact skills and behaviors that they learn in the city. They can afford to buy and then use technology that their covillagers usually refer to as "tools for men," and they extend parts of their independence to their mothers.

The case of the Indian telecenter operators is both similar to and different from the Chinese case. The villages where the centers were located had a substantial population engaged in activities related to agriculture. During the author's early visits to the project in Tamilnadu, the region was also facing a three-year long drought, which had led to many households desperately seeking some source of income. The regions under discussion were similar to the Chinese case for their 
strongly patriarchal value system. Few women worked outside the home in salaried positions. This was especially true of those whose families possessed land of their own and had the option of working in their own fields.

It was in these conditions that the telecenter projects we discuss were introduced by NGOs with the goal of being "inclusive." Besides focusing their work on low-income households, these NGOs worked hard to engage women as operators. The nonexistent or low stipend offered to operators ${ }^{5}$ made it likely that men would not take up or stay in these positions, which ironically also helped NGOs engage women. Especially when the excitement about the centers wore off, it was increasingly those who did not have other opportunities to gain salaried employment who would opt to be operators, which typically meant women (and increasingly, middle-aged women, as it became acceptable for a new generation of women to work the outside home).

Especially in the period during which we studied them, village telecenters offered the first exposure to computers for most of their users, including their operators. In both projects, computers were seen as sophisticated technologies that operators and village residents had to be persuaded to use in light of their fears of damaging an expensive technology. The Puducherry project even placed computers in everyday, nonthreatening locations (including placing one below a tree in the village square) to play down these fears. Over time, operators and some village residents became more comfortable with computers (partially due to the centers, but also because of other venues at which computers became accessible or at least visible, such as schools or public offices). That did not, however, change the fact that when computers were introduced through telecenters, their operators were seen as people who used sophisticated technology that most in the village did not know how to handle. Women operators referred to their pride when they were referred to as the "girl/ woman with the computer." The symbolic value of the computer too cannot be underestimated and played an important role in how an operator was regarded. This was especially significant for women who commented that prior to this visible role in the village, they were always referred to as somebody's daughter, wife, or sister. Since technology was largely associated with men in the communities we researched (or rather, only that which was used by men was seen as worthy of being called "technology"), the association with computers became even more important for women operators.

If these are changes experienced by operators in the public sphere, turning to the experiences of individual operators tells us more about changes in more "private" spheres of their

\footnotetext{
${ }^{5}$ In the Puducherry project, operators were initially volunteers.
}

lives. Lakshmi, an operator employed with the telecenter project in Tamilnadu since its inception in 2001, said her husband and parents-in-law were initially unhappy with her working, but were now proud of her. Her husband, a carpenter who worked from home, helped her with housework. Lakshmi continued to do most of the housework, albeit on a schedule that accommodated her work at the kiosk. She was unsure how long she could continue with her work as an operator, since her parents-in-law were getting old and required more assistance in their everyday routines. Lakshmi was not, at this stage, complaining that she was responsible for looking after her in-laws or that her husband was not. She was merely pondering how she would manage to balance both these sets of activities for which she felt responsible.

What complicates this story is that while Lakshmi liked her work at the center and the income she earned, she saw her husband as the primary breadwinner for the family. She appeared somewhat uneasy that her husband did not earn enough to provide his family a comfortable lifestyle with his earnings alone. Thus, while the availability of hitherto unavailable alternatives - of being ICT intermediaries - as well as being in salaried positions allowed women to question certain norms and expectations, as illustrated by Ling Hua and Lakshmi, this example also brings up the question of norms that persist, including among women ICT intermediaries.

\section{The Pull to Maintain Traditional Gender Roles}

As we began to see above in both the Indian and Chinese cases, ideas persist on how women ought to behave and what their role should be in the family, ideas that are often shared by the women themselves. The push toward change that is facilitated by ownership and proficiency in the use of ICTs is tempered by the expectation that women should always prioritize family over career, return to their traditionally mandated roles within the household after working outside for a while, and that men are better suited for the ICT-related work women had taken up.

Deng Xin was a returned migrant living with her husband and two children in a small village in China. She and her husband spent five years as migrant workers in Shanghai, where he learned how to use a computer and go online in an Internet café. Her husband taught her how to do so, and although she always struggled with inputting Chinese characters, with his help she could listen to music, watch movies, and use the instant messaging program QQ. She never achieved a completely autonomous use of the Internet, but since she frequented Internet cafés with him, she always had help right at hand. After the birth of their second child, they moved back 
to the village, and her husband started his own business as a house builder and painter. They bought a computer, but her husband thought that she wouldn't have any use for it, so stopped helping her when she wanted to go online. She had a number of friends from her Shanghai days on QQ, and would have liked to stay in touch, but after a while she gave up asking her husband for help. She occasionally called them on her phone, but overall reverted to a wholly village-focused life. Meanwhile, her husband went online regularly, and kept in touch with his Shanghai acquaintances and with urban trends and media content. Similar stories were quite common among returned migrant women, especially if they had children and did not work outside the village: they quickly found themselves reabsorbed into the traditional role they were expected to play in the family (and in the village), and their ties to the outside world were often forgotten, while their husbands maintained both contacts and independence.

Being a woman telecenter operator also had ramifications in the operators' families in the Indian countryside. The cases of Chinnaatha and Lakshmi, both middle-aged women operators in the Tamilnadu telecenter project, are telling. Chinnaatha confessed that her husband and his family, with whom she lived, were not supportive of her work. Chinnaatha's own mother, who lived in a neighboring village, supported her by taking care of her children during the week. Chinnaatha said that while everybody seemed to like the income she brought in, they resented the time she spent away from home and housework. This was in addition to her own guilt about the time she spent away from her children. Chinnaatha struggled constantly to balance the amount of time she thought she ought to spend at home and at work. She also tried, unsuccessfully, to engage her husband in the work she did. Chinnaatha said that she often despaired of carrying on in this way for long, especially once the drought subsided and she had fieldwork to attend to. But she did not want to give it up since she enjoyed her work at the center so much.

Nor was this "pull" toward traditional roles restricted to relationships within the family: it could ripple through to community-level expectations. The operators pointed out that their extended families and neighbors accused them of neglecting their families in tending to the center. At the same time, village residents would also assume that women operators could not do justice to the job given their domestic responsibilities. Relatedly, many residents also saw women operators as incompatible with the sophisticated technology they were handling. The center and computers were associated with educated people: time and again, residents without a formal school-based education in the Puducherry village said, "What will we do there? That's for the educated folks." Over time, as computers were introduced in schools and became generally more visible, the expectations became that operators should be educated people, who knew computers and English. Given the educational profile of the villages, this meant younger people and men. Residents were, therefore, not happy with the choice of local, middle-aged women as operators, women who were not highly educated (they had graduated class 8) and did not know English. Many parents complained that non-English speaking women who only had an eighth-grade degree could not possibly be doing a good job teaching computers to their kids. Further, operators themselves were not very confident of what they could teach students once students mastered the basics as the training from the NGO waned. Thus, the clash between who the NGO felt should be an operator and who the community wanted was experienced everyday by the female operators.

\section{Conclusion}

Our focus on process and agency allowed us to observe how our interviewees confronted social expectations around a woman's work-life balance, the implications of her financial independence for the family, her role within the family, and finally her ICT expertise vis-à-vis men in light of their new experiences. We find, thus, that in their role as ICT intermediaries, women are constantly engaged in negotiating their roles in a family and community. Moreover, the choices they make in the course of mediating ICT use always take place within a broader system of values and social expectations. In the Indian case, when women became telecenter operators, they found themselves negotiating their new roles and expectations with the NGO they worked for, their families, and the larger village community. We found that while women, in these negotiations, leveraged the opportunities and resources they acquired as a result of their association with telecenters, societal expectations (and their own) continued to be structured by patriarchal values. In the Chinese case, we saw how the combination of migration and financial independence allowed young women to challenge the patriarchal culture of their villages. These women, in turn, introduced ICTs to their female family members who, however, often remained dependent on both ICT mediators and social expectations in their ICT adoption and use. An urban experience that momentarily changed both the role and the familial and societal expectations of women could be reversed when the woman returned to her village and lost her financial independence. We emphasize that the renegotiation of gender roles, in both private and public spaces, is a process that inevitably takes a long time, and that can be supported by, but not entirely stem from, ICTs.

Our work provides several insights for IS research. First, we reiterate conclusions from IS research on intermediaries. We 
suggest that, rather than devoting all attention to end users, IS research should focus more on intermediaries and on the social context where both use and intermediation take place.

Second, based on our study, we point to the centrality of power structures and entrenched societal expectations in the process of mediating ICT use. While we examine this in the context of women's empowerment and in rural India and China, we argue that conflict over roles is equally constitutive of the process by which new information systems are accepted within other types of communities. This also points to the importance of understanding the structural reasons that underpin change, instead of focusing exclusively on individual behavior or the properties of ICTs. We believe such a shift would crucially shape the nature of the recommendations researchers are called upon to make. For example, in our case, it might mean placing less emphasis on ICTs and more on the need for collective and social support systems that enable female intermediaries to work against societal expectations where required (and indeed, several telecenter operators we interviewed spoke glowingly of the support they found in their newly acquired social network of NGO personnel and other women operators).

Our third insight is methodological. We illustrate the importance of focusing on processes, rather than only on outcomes, in order to understand the negotiations that exist around ICT use. The focus on process rather than outcome also allows us to understand that many factors feed into facilitating or inhibiting change. This, in turn, ensures that we move beyond a focus on a single variable (such as gender) which can risk perpetuating stereotypes (on gender as a variable and stereotypes - see Adam et al. 2004).

Our final insight is (indeed, has to be) broader. If we seek to build Information Systems as an inclusive field, we argue that there is a need to broaden who and what it studies. For example, the idea of a "business organization" in IS has historically referred to a corporate (and often Western) organization. This excludes alternative, equally legitimate ways of conducting business that are common in other parts of the world. Besides being more inclusive of other populations, organizing systems, and geographies, such a stance would also allow theoretically sophisticated understandings from other fields to illuminate concepts that are equally of interest to IS researchers. In our work, we attempt to achieve this by adopting a framework of empowerment from gender studies.

\section{Acknowledgments}

The authors would like to thank the MIS Quarterly editors, in particular M. Lynne Marcus, and the two anonymous reviewers for their constructive feedback. Oreglia's work was partially supported by the National Science Foundation under Grant No. 1027310. Srinivasan's work was supported by a number of research grants over the years, including from the Government of India, Infosys Technologies Bangalore, the second World Summit on Information Society Gender Caucus, the Peter Lyman Graduate Fellowship in New Media, and the Center for Budget Policy Studies Bangalore. The authors would like to thank their research participants for sharing their experiences and insights with them.

\section{References}

Adam, A., Griffiths, M., Keogh, C., Moore, K., Richardson, H., and Tattersall, A. 2006. "Being an 'it' in IT: Gendered Identities in IT Work," European Journal of Information Systems (15:4), pp. 368-378.

Adam, A., Howcroft, D., and Richardson, H. 2004. "A Decade of Neglect: Reflecting on Gender and IS," New Technology, Work and Employment (19:3), pp. 222-240.

Burrell, J. 2010. "Evaluating Shared Access: Social Equality and the Circulation of Mobile Phones in Rural Uganda," Journal of Computer-Mediated Communication (15), pp. 230-250.

CNNIC. 2013. " $31^{\text {st }}$ Statistical Report on Internet Development in China," Beijing, China.

Cohen, N. 2001. "What Works: Grameen Telecom's Village Phones," Washington, DC: World Resource Institute.

Corneliussen, H. 2005. "II Fell in Love with the Machine': Women's Pleasure in Computing," Journal of Information, Communication and Ethics in Society (3:4), pp. 233-241.

D'Mello, M., and Eriksen, T. H. 2010. "Software, Sports Day and Sheera: Culture and Identity Processes Within a Global Software Organization in India," Information and Organization (20:2), pp. 81-110.

Donner, J., and Marsden, G. 2011. "Exploring Mobile-Only Internet Use: Results of a Training Study in Urban South Africa," International Journal of Communication (5), pp. 574-597.

Economist. 2009. "Eureka Moments: How a Luxury Item Became a Tool of Global Development," The Economist, September 24 (http://www.economist.com/node/14483872).

Fan, C. C. 2004. "Out to the City and Back to the Village: The Experiences and Contributions of Rural Women Migrating from Sichuan and Anhui," in On the Move: Women and Rural-toUrban Migration in Contemporary China, A. M. Gaetano and T. Jacka (eds.), New York: Columbia University Press, pp. 177-206.

Fu, D. 2009. "A Cage of Voices: Producing and Doing Dagongmei in Contemporary China," Modern China (35:5), pp. 527-561.

Gaetano, A. M., and Jacka, T. 2004. On the Move: Women and Rural-to-Urban Migration in Contemporary China, New York: Columbia University Press.

Gill, K., Brooks, K., McDougall, J., Patel, P., and Kes, A. 2010. "Bridging the Gender Divide: How Technology Can Advance Women Economically," Washington DC: International Center for Research on Women (http://www.icrw.org/publications/ bridging-gender-divide). 
Gopakumar, K. R. 2008. "E-Governance Services Through Telecenters: The Role of Human Intermediary and Issues of Trust," Information Technologies \& International Development (4:1), pp. 19-35.

Howcroft, D., and Trauth, E. M. 2008. "The Implications of a Critical Agenda in Gender and IS Research," Information Systems Journal (18), pp. 185-202.

IIITB. 2005. "Information and Communications Technologies for Development: A Comparative Analysis of Impacts and Costs from India,” Department of Information Technology Bangalore, Ministry of Communications and Information Technology, Government of India, and Infosys Technologies, Bangalore.

Kabeer, N. 2001. "Reflections on the Measurement of Women's Empowerment," in Discussing Women's Empowerment: Theory and Practice, Uppsala, Sweden: Swedish International Development Cooperation Agency, pp. 17-57.

Kumar, R., and Best, M. L. 2006. "Impact and Sustainability of E-Government Services in Developing Countries: Lessons Learned from Tamil Nadu, India," The Information Society (22), pp. 1-12.

Kuriyan, R., Toyama, K., and Ray, I. 2006. "Integrating Social Development and Financial Sustainability: The Challenges of Rural Computer Kiosks in Kerala," in Proceedings of the International Conference on Information and Communication Technologies Development, Berkeley, CA, May 26-27, pp. 121-130.

Kvasny, L. 2006. "Let the Sisters Speak: Understanding Information Technology from the Standpoint of the 'Other,"' The DATA BASE for Advances in Information Systems (37:4), pp. 13-25.

Lamb, R., and Kling, R. 2003. "Reconceptualizing Users as Social Actors in Information Systems Research," MIS Quarterly (27:2), pp. 197-235.

Malhotra, A., Kanesathasan, A., and Patel, P. 2012. "Connectivity: How Mobile Phones, Computers and the Internet Can Catalyze Women's Entrepreneurship," International Center for Research on Women (Washington, DC) and Cherie Blair Foundation for Women (London).

Malhotra, A., Schuler, S. R., and Boender, C. 2002. "Measuring Women's Empowerment as a Variable in International Development," World Bank, Gender and Development Group.

Markus, M. L. 2001. "Toward A Theory of Knowledge Reuse: Types of Knowledge Reuse Situations and Factors in Reuse Success," Journal of Management Information Systems (18:1), pp. 57-93.

Medhi, I., Menon, S. R., Cutrell, E., and Toyama, K. 2010. "Beyond Strict Illiteracy: Abstracted Learning Among LowLiterate Users," in Proceedings of the International Conference on Information and Communication Technologies Development, London, December 13-16 (http://www.ethnosproject.org/ ictd2010-papers-posters-reports-more/).

Oreglia, E. 2013. From Farm to Farmville: Circulation, Adoption, and Use of ICT Between Urban and Rural China, unpublished Ph.D. Dissertation, University of California Berkeley.

Oreglia, E., and Kaye, J. J. 2012. "A Gift from the City: Mobile Phones in Rural China," in Proceedings of the ACM 2012 Conference on Computer Supported Cooperative Work, New York: ACM Press, pp. 137-146.
Pal, J., Pawar, U. S., Brewer, E. A., and Toyama, K. 2006. "The Case for Multi-User Design for Computer Aided," in Proceedings of the $15^{\text {th }}$ International World Wide Web, Edinburgh, Scotland, May 23-26, pp. 781-789.

Parikh, T. S. 2006. "Understanding and Designing for Intermediated Information Tasks in India," IEEE Pervasive Computing, pp. 32-39.

Pozzebon, M., Mackrell, D., and Nielsen, S. 2014. "Structuration Bridging Diffusion of Innovations and Gender Relations Theories: A case of paradigmatic pluralism in IS research," Information Systems Journal (24), pp. 229-248.

Ramírez, R., Parthasarathy, B., and Gordon, A. 2013. "From Infomediaries to Infomediation at Public Access Venues: Lessons from a 3-Country Study," in Proceedings of the International Conference on Information and Communication Technologies Development, Cape Town, South Africa, December 7-10, pp. 124-132.

Ravishankar, M. N., Pan, S. L., and Myers, M. D. 2012. "Information Technology Offshoring in India: A Postcolonial Perspective," European Journal of Information Systems (22:4), pp. 387-402.

Richardson, H. 2009. "Taking a Feminist Approach to Information Systems Research and Using the 'Thinking Tools' Provided by the Sociologist Pierre Bourdieu," Information Technology \& People (22:1), pp. 26-35.

Richardson, H. J., and Howcroft, D. 2006. "The Contradictions of CRM: A Critical Lens on Call Centres," Information and Organization (16:2), pp. 143-168.

Sambasivan, N., Cutrell, E., Toyama, K., and Nardi, B. 2010. "Intermediated Technology Use in Developing Communities," Proceedings of the $28^{\text {th }}$ International Conference on Human Factors in Computing Systems, New York: ACM Press, p. 2583.

Saumure, K., and Given, L. M. 2008. "Data Saturation," The SAGE Encyclopedia of Qualitative Research Methods, Thousand Oaks, CA: SAGE Publications, pp. 196-197.

Shen, A. X., Lee, M. K., Cheung, C. M., and Chen, H. 2010. "Gender Differences in Intentional Social Action: We-Intention to Engage in Social Network-Facilitated Team Collaboration," Journal of Information Technology (25:2), pp. 152-169.

Srinivasan, J. 2011. The Political Life of Information: 'Information' and the Practice of Governance in India, unpublished Ph.D. Dissertation, University of California Berkeley.

Srinivasan, J. 2012. "Looking Beyond 'Information Provision': The Importance of Being a Kiosk Operator in the Sustainable Access in Rural India (SARI) Project, Tamil Nadu, India," Information Technologies \& International Development (8:2), pp. 101-114.

Stanley, R. 2005. "Village Phone: A Tool for Empowerment," Washington, DC: Grameen Foundation.

Sukumaran, A., Ramlal, S., Ophir, E., Kumar, V. R., Mishra, G., Evers, V., Balaji, V., and Nass, C. 2009. "Intermediated Technology Interaction in Rural Contexts," in Proceedings of the $27^{\text {th }}$ International Conference on Human Factors in Computing Systems, New York: ACM Press, p. 3817.

Tapia, A. H. 2006. "Hostile Work Environment.Com: Increasing Participation of Underrepresented Groups, Lessons Learned from 
the Dot-Com Era," The DATA BASE for Advances in Information Systems (37:4), pp. 79-98.

Trauth, E. M. 2013. "The Role of Theory in Gender and Information Systems Research," Information and Organization (23:4), pp. 277-293.

Trauth, E. M., and Howcroft, D. 2006. "Critical Empirical Research in IS: An Example of Gender and the IT Workforce," Information Technology \& People (19:3), pp. 272-292.

Wallis, C. 2012a. "New Media Technologies in China's 'New Socialist Countryside': Techno-Sustenance and the Possibilities for Social Transformation," paper presented at the $10^{\text {th }}$ Chinese Internet Research Conference, Los Angeles, May 21-23.

Wallis, C. 2012b. Technomobility in China: Young Migrant Women and Mobile Phones, New York: New York University Press.

Yan, H. 2003. "Specialization of the Rural: Reinterpreting the Labor Mobility of Rural Young Women in Post-Mao China," American Ethnologist (30:4), pp. 578-596.

\section{About the Authors}

Elisa Oreglia is a research fellow at the Wee Kim Wee School of Communication and Information, Nanyang Technological University, Singapore. She received her Ph.D. from the Univesrity of California, Berkeley, School of Information. Her research focuses on the appropriation and circulation of mobile phones and computers among marginalized communities, particularly in China and Southeast Asia.

Janaki Srinivasan is a faculty member at the International Institute of Information Technology Bangalore. She received her Ph.D. from the University of California, Berkeley, School of Information and was a postdoctoral researcher at Virginia Polytechnic Institute and State University. Janaki uses qualitative methods to study the political economy of information and ICT use in poverty action initiatives.

\section{Appendix A}

Fieldwork

China $^{6}$

\begin{tabular}{|c|c|c|c|c|}
\hline Where & When & Who & What & Notes \\
\hline Beijing & $\begin{array}{l}\text { Jun-Aug } \\
2007\end{array}$ & $\begin{array}{l}\text { Female rural-to-urban migrant } \\
\text { workers; } 6 \text { key informants plus } \\
\text { other participants }\end{array}$ & $\begin{array}{l}\text { Open-ended, semi- } \\
\text { structured interviews; } \\
\text { observation; participant } \\
\text { observation; photographs }\end{array}$ & \\
\hline Beijing & $\begin{array}{l}\text { Jun-Sept } \\
2009\end{array}$ & $\begin{array}{l}4 \text { of the } 6 \text { original key infor- } \\
\text { mants, plus other participants, } \\
\text { including male rural-to-urban } \\
\text { migrant workers }\end{array}$ & $\begin{array}{l}\text { Open-ended, semi- } \\
\text { structured interviews; } \\
\text { observation; participant } \\
\text { observation; photographs }\end{array}$ & \\
\hline $\begin{array}{l}\text { Beijing, one village } \\
\text { in Southern Hebei } \\
\text { Province, two } \\
\text { villages in Western } \\
\text { Shandong } \\
\text { Province }\end{array}$ & $\begin{array}{l}\text { Jan-Oct } \\
2010\end{array}$ & $\begin{array}{l}\text { In Beijng, } 4 \text { of the } 6 \text { original } \\
\text { key informants, plus } 2 \text { new key } \\
\text { informants; around } 35 \text { rural } \\
\text { interviewees, mostly women of } \\
\text { all ages }\end{array}$ & $\begin{array}{l}\text { Open-ended, semi- } \\
\text { structured interviews; } \\
\text { observation; participant } \\
\text { observation; photographs }\end{array}$ & $\begin{array}{l}\text { Villages were the home-villages of } \\
\text { three key informants; one of the } \\
\text { objectives of the research was to } \\
\text { trace the links between Beijing and } \\
\text { migrants' villages. Thus fieldwork } \\
\text { started in Beijing; continued in } \\
\text { migrants' villages, where the } \\
\text { researcher stayed in their homes for } \\
1-2 \text { weeks; continued back in Beijing } \\
\text { to find co-villagers who had moved } \\
\text { there; continued back in the country- } \\
\text { side, with a back-and-forth pattern } \\
\text { that went on for the entire year }\end{array}$ \\
\hline $\begin{array}{l}\text { Same locations as } \\
2010\end{array}$ & $\begin{array}{l}\text { Jun-Sept } \\
2011\end{array}$ & $\begin{array}{l}\text { Same informants and inter- } \\
\text { viewees as above, plus around } \\
15 \text { new interviewees in the } \\
\text { countryside, equally distributed } \\
\text { between men and women }\end{array}$ & $\begin{array}{l}\text { Semi-structured interviews; } \\
\text { observation; participant } \\
\text { observation; photographs }\end{array}$ & $\begin{array}{l}\text { Follow-up visit after the first round of } \\
\text { analysis, to clarify and fill gaps in the } \\
\text { data gathered until then }\end{array}$ \\
\hline
\end{tabular}

${ }^{6}$ In all field sites, interviews were carried out in Chinese and recorded unless participants requested this not be done, in which case notes were taken. Interviews were subsequently transcribed, translated, and coded, as were field diaries, photos, and other material gathered during the research. 
India $^{7}$

\begin{tabular}{|c|c|c|c|c|}
\hline Where & When & Who & What & Notes \\
\hline $\begin{array}{l}\text { Sustainable } \\
\text { Access in Rural } \\
\text { India project, Melur } \\
\text { taluk, Madurai } \\
\text { district, TamilNadu }\end{array}$ & $\begin{array}{l}6 \text { weeks of } \\
\text { summer } \\
2004\end{array}$ & $\begin{array}{l}\text { Telecenter project personnel; } \\
\text { telecenter operators, users, } \\
\text { non-users and the families of } \\
\text { telecenter operators; village } \\
\text { administrative officials and } \\
\text { government officials con- } \\
\text { nected to the administration of } \\
\text { the egovernance component of } \\
\text { the project; six key informants } \\
\text { (5 women, } 1 \text { man) identified } \\
\text { among telecenter operators }\end{array}$ & $\begin{array}{l}\text { Observation and semi- } \\
\text { structured interviews at } \\
\text { the telecenter, in village } \\
\text { public spaces and at the } \\
\text { homes of operators; } \\
\text { attending telecenter } \\
\text { operator meetings; } \\
\text { telecenter usage details } \\
\text { from user notebooks and } \\
\text { project reports }\end{array}$ & $\begin{array}{l}\text { After visits to } 20 \text { active telecenters (of } \\
\text { a possible 52) and conversations with } \\
\text { project personnel and operators, } 6 \\
\text { telecenters were picked for detailed } \\
\text { study on the basis of the organization } \\
\text { operating them (non-profit vs. private), } \\
\text { their rating by the project, levels of } \\
\text { activity, the size of the village, and the } \\
\text { gender of its operator. The detailed } \\
\text { study involved observation in the } \\
\text { villages where the telecenters were } \\
\text { located and in the village where the } \\
\text { operator was based. }\end{array}$ \\
\hline $\begin{array}{l}\text { Sustainable } \\
\text { Access in Rural } \\
\text { India project, Melur } \\
\text { taluk, Madurai } \\
\text { district, TamilNadu }\end{array}$ & $\begin{array}{l}6 \text { weeks of } \\
\text { summer } \\
2004\end{array}$ & $\begin{array}{l}\text { Telecenter project personnel; } \\
\text { telecenter operators, users, } \\
\text { non-users and the families of } \\
\text { telecenter operators; three of } \\
\text { the original informants con- } \\
\text { tinued to be key informants }\end{array}$ & $\begin{array}{l}\text { Observation and semi- } \\
\text { structured interviews at } \\
\text { telecenters, in village } \\
\text { public spaces and at the } \\
\text { homes of operators; } \\
\text { attending telecenter } \\
\text { operator meetings; tele- } \\
\text { center usage details from } \\
\text { user notebooks and } \\
\text { project reports }\end{array}$ & $\begin{array}{l}\text { Focused on the three telecenters } \\
\text { operated by a nonprofit for a detailed } \\
\text { study of their evolution since the last } \\
\text { visit. }\end{array}$ \\
\hline $\begin{array}{l}\text { Sustainable } \\
\text { Access in Rural } \\
\text { India project, Melur } \\
\text { taluk, Madurai } \\
\text { district, TamilNadu }\end{array}$ & $\begin{array}{l}\text { Short } \\
\text { visits in } \\
2007 \text { and } \\
2009\end{array}$ & $\begin{array}{l}\text { Same project personnel, } \\
\text { telecenter operators and } \\
\text { families }\end{array}$ & $\begin{array}{l}\text { Semi-structured } \\
\text { interviews at project } \\
\text { headquarters and homes } \\
\text { of telecenter operators }\end{array}$ & $\begin{array}{l}\text { Interviews to understand the evolution } \\
\text { of the project and individual operator } \\
\text { trajectories since the previous visit. }\end{array}$ \\
\hline $\begin{array}{l}\text { Swaminathan } \\
\text { Foundation's } \\
\text { Information Village } \\
\text { Research Project, } \\
\text { Puducherry district }\end{array}$ & $\begin{array}{l}\text { July- } \\
\text { November } \\
2009\end{array}$ & $\begin{array}{l}\text { Telecenter project personnel; } \\
\text { telecenter operators, users, } \\
\text { non-users and the families of } \\
\text { telecenter operators; village } \\
\text { administrative officials and } \\
\text { politicians; four women } \\
\text { telecenter operators (attached } \\
\text { to } 2 \text { telecenters) identified as } \\
\text { key informants }\end{array}$ & $\begin{array}{l}\text { Observation and semi- } \\
\text { structured interviews at } \\
\text { the project headquarters, } \\
\text { at telecenters, in village } \\
\text { public spaces and at the } \\
\text { homes of operators; } \\
\text { attending telecenter } \\
\text { operator meetings tele- } \\
\text { center usage details from } \\
\text { user notebooks and } \\
\text { project reports }\end{array}$ & $\begin{array}{l}\text { Following visits to all operational tele- } \\
\text { centers (about } 15 \text { active) and conver- } \\
\text { sations with project personnel and } \\
\text { operators, } 2 \text { telecenters (one in an } \\
\text { agricultural village, the other in a } \\
\text { fishing village) were picked for detailed } \\
\text { study. Detailed study of a center } \\
\text { involved spending the day at the } \\
\text { telecenter and a house-by-house } \\
\text { survey of users and non-users in the } \\
\text { village. }\end{array}$ \\
\hline
\end{tabular}

\footnotetext{
${ }^{7}$ Interviews were carried out in Tamil and in English. They were recorded with the participants' consent. Where recording was not possible, notes were taken. Interviews were subsequently transcribed, translated, and coded, as were field diaries, photos, and other material gathered during the research.
} 